\title{
Congenital chloride diarrhoea
}

\author{
Clinical analysis of 21 Finnish patients
}

\author{
C. HOLMBERG, J. PERHEENTUPA, K. LAUNIALA,* AND N. HALlMAN \\ From the Children's Hospital, University of Helsinki, Finland
}

SUMMARY Clinical findings in 21 Finnish children with congenital chloride diarrhoea are reported. Inheritance of this disease by the autosomal recessive mode is established. All children were born 1-8 weeks prematurely. Hydramnios was present in every case and no meconium was observed; intrauterine onset of diarrhoea is thus apparent. In most cases the diarrhoea or passing of large volumes of 'urine' was noted on the first day of life and the abdomen was usually large and distended. The neonatal weight loss was abnormally large, and was associated with hypochloraemia and hyponatraemia. Some infants survived the neonatal period without adequate therapy. They presented later with failure to thrive and usually had hypochloraemia, hypokalaemia, and metabolic alkalosis associated with hyperaldosteronism. However, these features may be absent and the diagnosis is based on a history of hydramnios and diarrhoea, and a faecal $\mathrm{Cl}^{-}$concentration which always exceeds $90 \mathrm{mmol} / \mathrm{l}$ when fluid and electrolyte deficits have been corrected. Lower faecal $\mathrm{Cl}^{-}$ concentrations were seen only in chronic hypochloraemia, which is also associated with achloriduria.

Adequate treatment consists of full continuous replacement of the faecal losses of water, $\mathrm{NaCl}$, and $\mathrm{KCl}$. This should be given intravenously in the early neonatal period; later a solution can be taken orally with meals. The dose has to be adjusted to maintain normal serum electrolyte concentrations, normal blood $p \mathrm{H}$, and some chloriduria. This therapy prevents the renal lesions and the retarded growth and psychomotor development which were seen in the children who were diagnosed late and in those who received inadequate replacement therapy. The watery diarrhoea persists and increases slightly with age, though patients learn to live with their disease and to make an adequate social adjustment.

In 1945 Gamble et al. and Darrow both described a child who had persistent watery diarrhoea, a high faecal concentration of $\mathrm{Cl}^{-}$, hypochloraemia: hypokalaemia, and metabolic alkalosis, and they diagnosed the illness as 'congenital alkalosis with diarrhoea'. Since then 19 more cases have been reported from outside Finland: from the United States (Kelsey, 1954; Owen, 1964; Tucker et al., 1964; McReynolds, et al., 1974); the Netherlands (Duyck, 1955); the United Kingdom (Evanson and Stanbury, 1965; Harries, 1969; Davidson et al., 1972; Lee and Harries, 1973; Pearson et al., 1973); France (Harteman, 1966; Chaptal et al., 1967; Lauras et al., 1973); Denmark (Yssing and Friis-Hansen, 1966); Japan (Yanagisawa, et al., 1968); Belgium (Loeb et al., 1970); Norway (Michal-

Received 3 July 1976

*Present address: Department of Paediatrics, University of Kuopio, 70210 Kuopio 21, Finland sen, 1972); Poland (Hager-Malecka et al., 1973); and Germany (Bremer and Heinisch, 1973).

In Finland this disease, which we prefer to call congenital chloride diarrhoea (CCD), was diagnosed for the first time in 1960, and since then an average of 2 new cases have been diagnosed annually (Perheentupa et al., 1965; Launiala et al., 1968; Norio et al., 1971). We have now treated 21 children with CCD; 3 have died.

CCD is inherited as an autosomal recessive trait, which implies an abnormality in a single gene pair, a single protein, and a single cell function (Norio et al., 1971). Launiala et al., (1968) showed that the intestinal defect is located in the distal ileum and colon. Studies of the ileum (Turnberg, 1971; Bieberdorf et al., 1972; Pearson et al., 1973) and colon (Lauras et al., 1973; Pearson et al., 1973; Holmberg et al., 1975) have shown, moreover, that this defect is impaired active $\mathrm{Cl}^{-}$absorption probably resulting from an absence or impairment of the 
$\mathrm{Cl}^{-} / \mathrm{HCO}_{3}^{-}$exchange mechanism in these segments of the intestine. $\mathrm{Cl}^{-}$is lost into the stools and osmotic diarrhoea develops. The absence of $\mathrm{HCO}_{3}^{-}$causes the intestinal contents to become acid which in turn restricts the absorption of $\mathrm{Na}^{+}$. Secretion of $\mathrm{K}^{+}$is increased (Holmberg, et al., 1975).

This paper describes the Finnish CCD patients, their clinical picture, their physical and psychomotor development, and our method of treatment. The pathophysiology and the renal lesion will be discussed in detail elsewhere (Holmberg, 1977; Holmberg et al., 1977).

\section{Antenatal manifestations}

Fetal diarrhoea. Hydramnios (2-6 l) always heralded the birth of a child with CCD. This suggests that the diarrhoea begins in utero. Further evidence of this is the lack of meconium noted in 14 infants carefully observed on the first day of life. All these infants had diarrhoea from birth. In the amniotic fluid of 2 patients the concentration of $\mathrm{Na}^{+}$was $126 \mathrm{mmol} / 1$ $(126 \mathrm{mEq} / \mathrm{l})$ in both, $\mathrm{K}^{+} 3.4$ and $4.4 \mathrm{mmol} / \mathrm{l}$ (3.4, $4.4 \mathrm{mEq} / \mathrm{l})$, and $\mathrm{Cl}^{-} 102$ and $108 \mathrm{mmol} / \mathrm{l}$ $(102,108 \mathrm{mEq} / \mathrm{l})$, respectively. In the first of these infants serum electrolyte concentrations at 2 hours were $\mathrm{Na}^{+} 105, \mathrm{~K}^{+} 4 \cdot 0$, and $\mathrm{Cl}^{-} 81 \mathrm{mmol} / \mathrm{l}$, and the faecal concentration of $\mathrm{Cl}^{-}$at 24 hours $134 \mathrm{mmol} / \mathrm{l}$. Electrolyte concentrations in the amniotic fluid in CCD are therefore normal. CCD should be considered in cases of hydramnios, especially in a woman who has had previous hydramnios resulting in perinatal death. CCD cannot be verified through amniocentesis.

Length of gestation. All 21 infants were born before term and 19 by 2 weeks or more (Table 1). Prematurity is presumably a consequence of the hydramnios.

Fetal growth. The lengths and weights at birth are shown in Fig. 1. The mean length was normal for the duration of gestation. The mean weight was slightly higher, probably owing to the intestinal accumulation of water. Most infants were born with a distended abdomen.

\section{Neonatal manifestations}

Diarrhoea. In 14 patients diarrhoea and an absence of meconium were noticed on the first day of life. Diarrhoea often goes unnoticed because the fluid in the diaper is thought to be urine. In fact, several patients in whom diarrhoea was not observed were reported to have passed large volumes of urine. On the first day of life about $150 \mathrm{ml}$ fluid was lost with the stools. The $\mathrm{Cl}^{-}$concentration in this fluid was $100-150$, usually about $130 \mathrm{mmol} / \mathrm{l}$. During the first 3 months of life the sum of the concentrations of $\mathrm{Na}^{+}$ and $\mathrm{K}^{+}$usually exceeded the concentration of $\mathrm{Cl}^{-}$ (Fig. 2). This is in contrast to the situation which has been observed regularly beyond age 3 months. Stool $p \mathrm{H}$ was between 4 and 6 .

Table 1 Neonatal characteristics of 21 patients with congenital chloride diarrhoea (CCD)

\begin{tabular}{|c|c|c|c|c|c|c|}
\hline Patient & $\begin{array}{l}\text { Duration of } \\
\text { gestation }(w)\end{array}$ & $\begin{array}{l}\text { Age } \\
\text { diarrhoea } \\
\text { noticed }\end{array}$ & $\begin{array}{l}\text { Bilirubinaemia* } \\
(\mathrm{mg} / 100 \mathrm{ml})\end{array}$ & $\begin{array}{l}\text { Distended } \\
\text { abdomen }\end{array}$ & $\begin{array}{l}\text { Neonatal weight } \\
\text { loss }(\% \text { of } \\
\text { birthweight })\end{array}$ & $\begin{array}{l}\text { Age CCD } \\
\text { diagnosed }\end{array}$ \\
\hline $\begin{array}{l}\text { RK } \\
\text { MK } \\
\text { RKo } \\
\text { AS } \\
\text { RJ } \\
\text { JT } \\
\text { LI } \\
\text { PI } \\
\text { JH } \\
\text { MH } \\
\text { J-PK } \\
\text { MV } \\
\text { RV } \\
\text { MKu } \\
\text { SA } \\
\text { AT } \\
\text { KR } \\
\text { HP } \\
\text { TR } \\
\text { JK } \\
\text { A-JS }\end{array}$ & $\begin{array}{l}34 \\
37 \\
34 \\
34 \\
34 \\
34 \\
36 \\
39 \\
38 \\
34 \\
37 \\
37 \\
34 \\
33 \\
34 \\
35 \\
36 \\
36 \\
35 \\
36 \\
32\end{array}$ & $\begin{array}{l}3 \mathrm{w} \\
1 \mathrm{~d} \\
4 \mathrm{~m} \\
1 \mathrm{~d} \\
1 \mathrm{~d} \\
1 \mathrm{~d} \\
6 \mathrm{~m} \\
11 \mathrm{~d} \\
3 \mathrm{w} \\
1 \mathrm{~d} \\
1 \mathrm{~d} \\
3 \mathrm{~m} \\
1 \mathrm{~d} \\
1 \mathrm{~d} \\
1 \mathrm{~d} \\
3 \mathrm{w} \\
1 \mathrm{~d} \\
1 \mathrm{w} \\
1 \mathrm{~d} \\
1 \mathrm{~d} \\
1 \mathrm{~d}\end{array}$ & $\begin{array}{l}23 \cdot 3 \ddagger \\
27 \cdot 0 \dagger \\
29 \cdot 9 \\
24 \cdot 2 \\
30 \cdot 0 \S \\
15 \cdot 0 \\
26 \cdot 0 \dagger \\
24 \cdot 6 \\
18 \cdot 4 \\
21 \cdot 0 \\
22 \cdot 0 \\
21 \cdot 0 \dagger \\
18 \cdot 0 \\
23 \cdot 0 \\
17 \cdot 2 \\
12 \cdot 3 \\
20 \cdot 0\end{array}$ & $\begin{array}{l}+ \\
+ \\
+ \\
+ \\
\\
\\
+ \\
+ \\
+ \\
+ \\
+ \\
+ \\
+ \\
+ \\
+ \\
+ \\
+\end{array}$ & $\begin{array}{l}20 \cdot 2 \\
14 \cdot 2 \\
19 \cdot 5 \\
26 \cdot 6 \\
12 \cdot 7 \\
27 \cdot 2 \\
18 \cdot 0 \\
14 \cdot 4 \\
23 \cdot 9 \\
16 \cdot 7 \\
26 \cdot 9 \\
\text { n.d. } \\
11 \cdot 0 \\
23 \cdot 9 \\
20 \cdot 5 \\
15 \cdot 8 \\
22 \cdot 4 \\
26 \cdot 5 \\
15 \cdot 3 \\
12 \cdot 6 \\
17 \cdot 8\end{array}$ & $\begin{array}{c}5 \mathrm{~d} \\
8 \mathrm{~m} \\
9 \mathrm{~m} \\
4 \mathrm{~m} \\
2 \mathrm{~m} \\
14 \mathrm{~m} \\
3 \mathrm{~d} \\
3 \mathrm{w} \\
1 \mathrm{~d} \\
3 \mathrm{~d} \\
4 \mathrm{~m} \\
1 \mathrm{~d} \\
1 \mathrm{~d} \\
1 \mathrm{~d} \\
25 \mathrm{~m} \\
2 \mathrm{~m} \\
2 \mathrm{~m} \\
1 \mathrm{~d} \\
1 \mathrm{~d} \\
1 \mathrm{~d}\end{array}$ \\
\hline
\end{tabular}

*Highest concentration measured. Blood group incompatibility present: †A, †B, §D. Conversion: Traditional units to SI-Bilirubin: 1 mg/ $100 \mathrm{ml} \approx 17 \cdot 1 \mu \mathrm{mol} / \mathrm{l}$. 


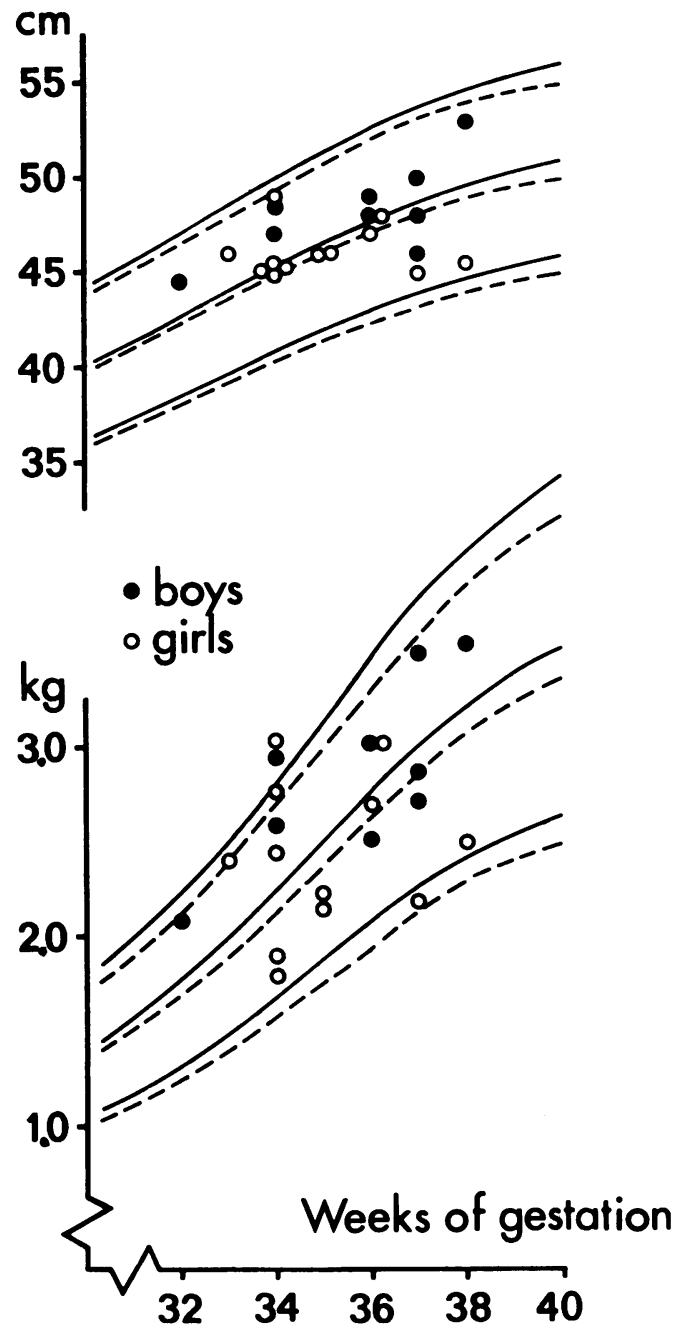

Fig. 1 Birth lengths and weights of 21 children with $C C D$. The lines indicate normal mean $\pm 2 \cdot 5 S D$. boys; - - - girls.

Abdominal distension. The abdomen was usually large and distended (Fig. 3) and was often the reason for admission to hospital. Movements of the bowel were visible. Several patients were suspected of having an intestinal occlusion and an aganglionic segment. $X$-rays showed that loops of ileum and colon were dilated with air and fluid (Fig. 4). In all but one infant this state of paralytic ileus lasted several weeks, finally subsiding on conservative therapy. In patient TR a volvulus developed at 8 weeks. This complication has been reported in 3 other CCD patients (Tucker et al., 1964; Lee and Harries, 1973; Pearson et al., 1973). A constant

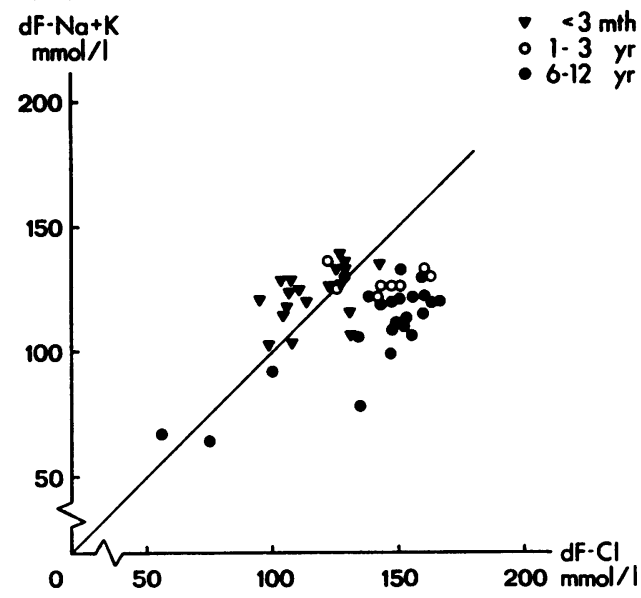

Fig. 2 Relationship of the sum of the concentrations of $\mathrm{Na}^{+}$and $\mathrm{K}^{+}$to the concentration of $\mathrm{Cl}^{-}$in the faeces $(d F)$ of $C C D$ patients at different ages. Conversion: SI to traditional units-Electrolytes $: 1 \mathrm{mmol} / \mathrm{l}=1 \mathrm{mEq} / \mathrm{l}$.

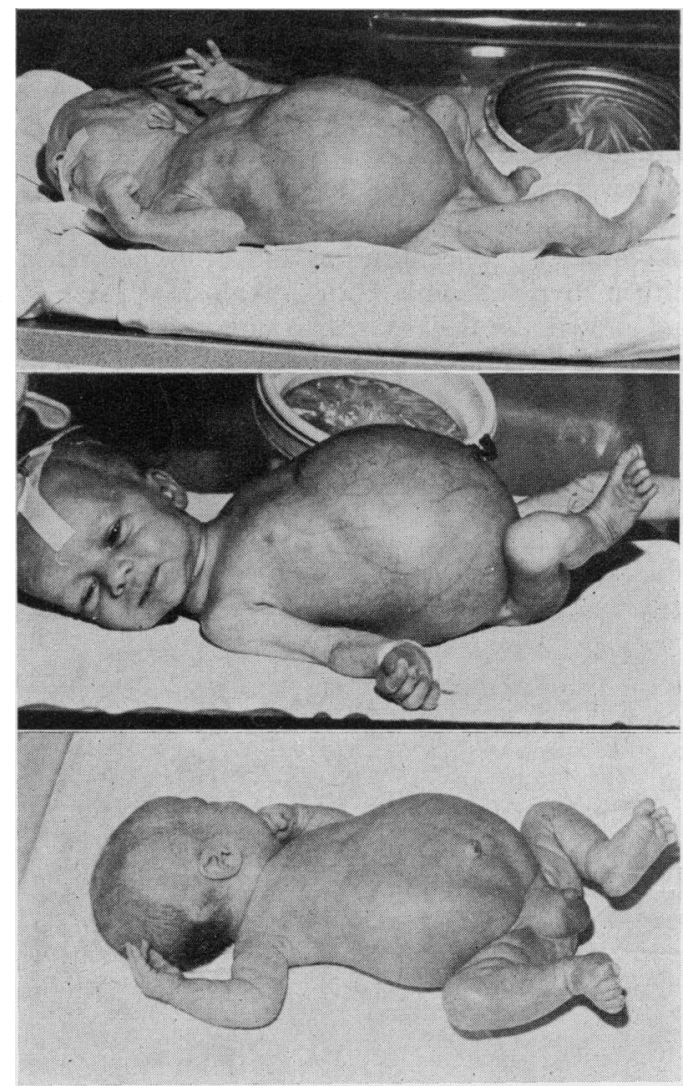

Fig. 3 Appearance of 3 newborn CCD patients. 


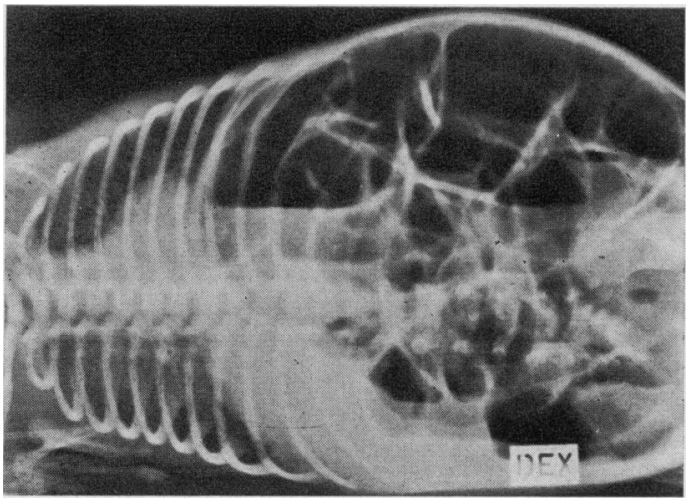

Fig. 4 X-ray of the distended abdomen of a newborn $C C D$ patient. Intestinal loops are dilated with fluid and air and a hydroperitoneum is present.

voluminous filling of intestinal loops probably creates a predisposition to a volvulus.

Total exchangeable $\mathrm{K}^{+}$estimated in two 4-weekold patients whose abdomens continued to be severely distended was 32.2 and $34 \cdot 3 \mathrm{mmol} / \mathrm{kg}$, respectively, slightly below normal $(38-46 \mathrm{mmol} / \mathrm{kg})$. Such a mild $\mathrm{K}^{+}$depletion is unlikely to cause intestinal atonia.

Water, electrolyte, and acid-base status. Because CCD was suspected in patient RV at birth serum electrolyte and $p \mathrm{H}$ status were determined at 1 hour. $\mathrm{Na}^{+}$and $\mathrm{Cl}^{-}$concentrations were low but he had neither hypokalaemia nor alkalosis (Table 2). In 5 others serum electrolyte concentrations were measured 20-30 hours after birth but before weight loss, by then about $7 \cdot 7-13.0 \%$ of birthweight, had been replaced. All concentrations were normal. In 6 others these values were first recorded, also before treatment, at the age of 7 days. Most patients had clear hyponatraemia and hypochloraemia (Table 2), whereas only 2 had low concentrations of $\mathrm{K}^{+}$. Fig. 5 shows that the neonates reacted to the fluid loss with a hypo-osmolality associated with hyponatraemia, hypochloraemia, and a slight rise in $\mathrm{HCO}_{3}^{-}$concentrations.

The inability to maintain a normal concentration of $\mathrm{Na}^{+}$in the first weeks of life suggests an immaturity of the aldosterone system. Because excretion of $p \mathrm{H} 1$ hydrolysable aldosterone (Bayard et al., 1970) was $2 \cdot 3 \mu \mathrm{g} / \mathrm{m}^{2}$ per $24 \mathrm{~h}$ in the first day in patient $\mathrm{RV}$ and $7.6 \mu \mathrm{g} / \mathrm{m}^{2}$ per $24 \mathrm{~h}$ on the third day in $\mathrm{JK}$, aldosterone production did not seem to be impaired in the newborn (normal range 2-12 $\mu \mathrm{g} / \mathrm{m}^{2}$ per $24 \mathrm{~h}$ ). At the age of 7 days only one child was alkalotic, the others were clearly acidotic. Thus although the diarrhoea of CCD is congenital, the alkalosis is not, and the original name of this disease, 'congenital alkalosis with diarrhoea' is a misnomer. If sufficient replacement therapy was not started during the first weeks, severe alkalosis developed and the plasma concentrations of $\mathrm{Cl}^{-}, \mathrm{K}^{+}$, and $\mathrm{Na}^{+}$ fell, the lowest values in our patients being $p \mathrm{H} \mathrm{7.68}$ and electrolytes $54,1 \cdot 7$, and $107 \mathrm{mmol} / 1$ respectively.

Most patients will probably not survive if adequate replacement therapy is not provided at this stage. 7 of the previous infant deaths in the 18 families we studied were probably due to CCD. These infants were born prematurely after hydramnios and died in the first months of life with distended abdo-

Table 2 Serum (blood) electrolyte concentrations (mmol/l) and $\mathrm{pH}$ before diagnosis and treatment

\begin{tabular}{|c|c|c|c|c|c|c|c|c|}
\hline \multirow[t]{2}{*}{ Patient } & \multirow[t]{2}{*}{ Age } & \multirow{2}{*}{$\begin{array}{l}\text { Weight loss } \\
\text { (\% of } \\
\text { birthweight) }\end{array}$} & \multicolumn{3}{|c|}{ Serum } & \multicolumn{3}{|l|}{ Blood } \\
\hline & & & $\mathrm{Na}^{+}$ & $\boldsymbol{K}^{+}$ & $\mathrm{Cl}^{-}$ & $\mathrm{p} H$ & $\begin{array}{l}\text { Standard } \\
\text { bicarbonate }\end{array}$ & Base excess \\
\hline RV & $1 \mathrm{~h}$ & ND & 105 & $4 \cdot 0$ & 81 & $7 \cdot 24$ & $19 \cdot 1$ & $-6 \cdot 6$ \\
\hline $\begin{array}{l}\text { MH } \\
\text { MKu } \\
\text { SA } \\
\text { TR } \\
\text { A-JS }\end{array}$ & $\begin{array}{ll}1 & d \\
1 & d \\
1 & d \\
1 & d \\
1 & d\end{array}$ & $\begin{array}{r}8 \cdot 3 \\
9 \cdot 6 \\
10 \cdot 5 \\
13 \cdot 0 \\
7 \cdot 7\end{array}$ & $\begin{array}{l}148 \\
148 \\
148 \\
144 \\
133\end{array}$ & $\begin{array}{l}4 \cdot 3 \\
7 \cdot 9 \\
7 \cdot 2 \\
5 \cdot 5 \\
5 \cdot 2\end{array}$ & $\begin{array}{r}109 \\
117 \\
96 \\
108 \\
97\end{array}$ & $\begin{array}{l}\text { ND } \\
7 \cdot 42 \\
7 \cdot 28 \\
\text { ND } \\
7 \cdot 34\end{array}$ & $\begin{array}{l}\text { ND } \\
22 \cdot 0 \\
18 \cdot 7 \\
\text { ND } \\
21 \cdot 5\end{array}$ & $\begin{array}{l}\text { ND } \\
-2 \cdot 4 \\
-7 \cdot 7 \\
\text { ND } \\
-3 \cdot 6\end{array}$ \\
\hline $\begin{array}{l}\text { RK } \\
\text { JT } \\
\text { MH } \\
\text { J-PK } \\
\text { MK } \\
\text { SA }\end{array}$ & $\begin{array}{l}7 \mathrm{~d} \\
7 \mathrm{~d} \\
7 \mathrm{~d} \\
7 \mathrm{~d} \\
7 \mathrm{~d} \\
7 \mathrm{~d}\end{array}$ & $\begin{array}{l}19 \cdot 5 \\
27 \cdot 2 \\
22 \cdot 3 \\
20 \cdot 8 \\
23 \cdot 9 \\
20 \cdot 5\end{array}$ & $\begin{array}{l}123 \\
122 \\
110 \\
128 \\
127 \\
124\end{array}$ & $\begin{array}{l}2 \cdot 6 \\
2 \cdot 4 \\
5 \cdot 6 \\
4 \cdot 0 \\
3 \cdot 5 \\
3 \cdot 7\end{array}$ & $\begin{array}{l}83 \\
72 \\
76 \\
68 \\
88 \\
87\end{array}$ & $\begin{array}{l}7 \cdot 34 \\
7 \cdot 42 \\
7 \cdot 39 \\
7 \cdot 42 \\
\text { ND } \\
\text { ND }\end{array}$ & $\begin{array}{l}20 \cdot 3 \\
20 \cdot 8 \\
21 \cdot 2 \\
30 \cdot 5 \\
\text { ND } \\
\text { ND }\end{array}$ & $\begin{array}{l}-4 \cdot 1 \\
-4 \cdot 0 \\
-3 \cdot 5 \\
+8 \cdot 8 \\
\text { ND } \\
\text { ND }\end{array}$ \\
\hline $\begin{array}{l}\text { RJ } \\
\text { MV } \\
\text { LI } \\
\text { AT }\end{array}$ & $\begin{array}{l}16 \mathrm{w} \\
18 \mathrm{w} \\
14 \mathrm{~m} \\
24 \mathrm{~m}\end{array}$ & $\begin{array}{c}\text { ND } \\
\text { ", } \\
\text { ", }\end{array}$ & $\begin{array}{l}128 \\
134 \\
133 \\
137\end{array}$ & $\begin{array}{l}3 \cdot 3 \\
2 \cdot 8 \\
2 \cdot 6 \\
3 \cdot 7\end{array}$ & $\begin{array}{l}80 \\
57 \\
85 \\
80\end{array}$ & $\begin{array}{l}7 \cdot 39 \\
7 \cdot 68 \\
7 \cdot 51 \\
7 \cdot 52\end{array}$ & $\begin{array}{l}35 \cdot 0 \\
40 \cdot 0 \\
28 \cdot 0 \\
32 \cdot 0\end{array}$ & $\begin{array}{r}+12.0 \\
+18.0 \\
+5.0 \\
+10.1\end{array}$ \\
\hline
\end{tabular}

${ }^{*} \mathrm{ND}=$ not determined. Conversion: $S I$ to traditional units-Electrolytes: $1 \mathrm{mmol} / 1=1 \mathrm{mEq} / \mathrm{l}$. 

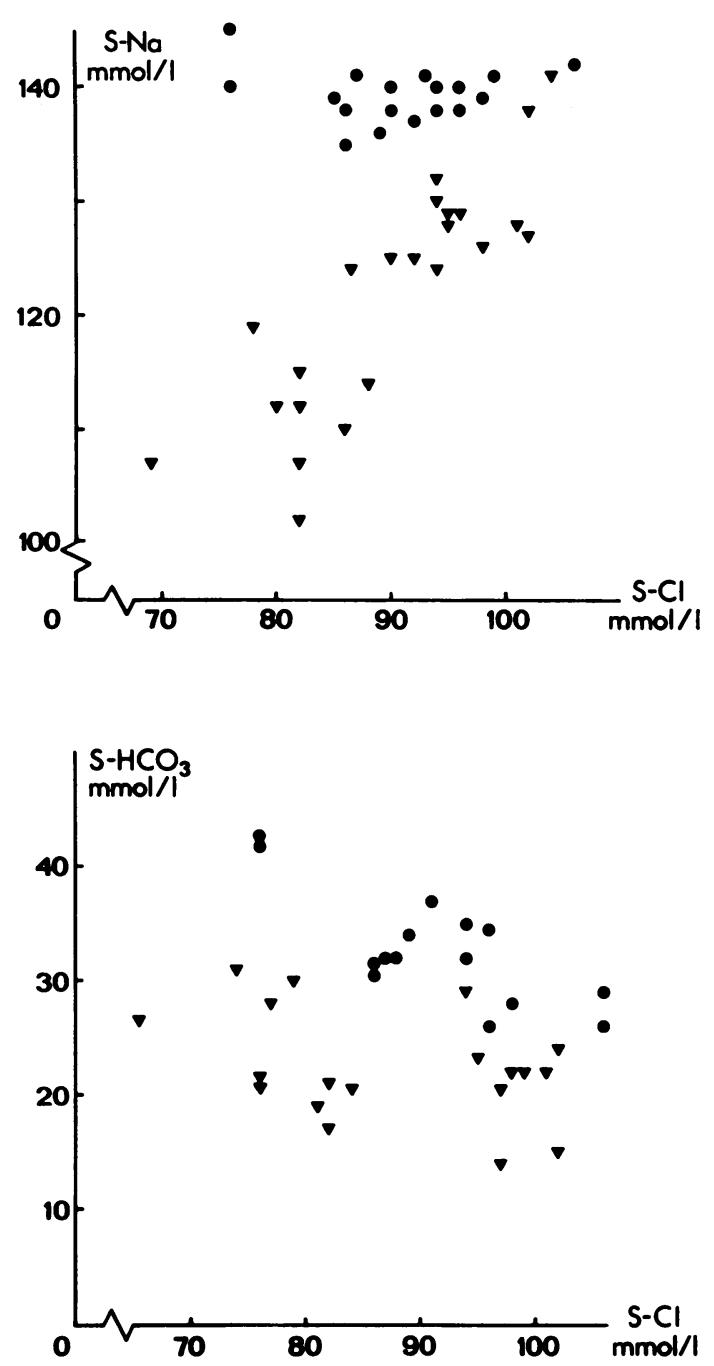

Fig. 5 Relationship of $(\mathrm{S})$ serum $\mathrm{Na}^{+}$and serum $\mathrm{HCO}_{3}^{-}$ concentrations to the serum $\mathrm{Cl}^{-}$concentration in newborn $(\nabla=<1 \mathrm{~m})$ and older $(\Theta=>1 \mathrm{~m}) C C D$ patients.

men and diarrhoea. There were other early deaths in these families in unknown circumstances; such cases have been labelled as 'possible CCD' in Table 3. Patient MKu died at 19 days of age because intravenous replacement of existing deficits was insufficient. Infants in whom intravenous replacement of water and electrolytes was adequate from the first day of life remained free of electrolyte and $p \mathrm{H}$ disturbances and had continuous chloriduria (Table 4).

Jaundice. Most patients had hyperbilirubinaemia. 7 patients required one or more exchange transfu-
Table 3 Finnish CCD sibships

\begin{tabular}{|c|c|c|}
\hline Patients & Year of birth & Sibship \\
\hline $\begin{array}{l}\text { RK \& MK } \\
\text { RKo } \\
\text { AS } \\
\text { RJ } \\
\text { JT } \\
\text { LI \& PI } \\
\text { JH } \\
\text { MH } \\
\text { J-PK } \\
\text { MV \& RV } \\
\text { MKu } \\
\text { SA } \\
\text { AT } \\
\text { KR } \\
\text { HP } \\
\text { TR } \\
\text { JK } \\
\text { A-JS }\end{array}$ & $\begin{array}{l}1960,1961 \\
1963 \\
1963 \\
1964 \\
1964 \\
1964,1966 \\
1965 \\
1966 \\
1966 \\
1967,1973 \\
1969 \\
1970 \\
1971 \\
1971 \\
1971 \\
1972 \\
1974 \\
1974\end{array}$ & 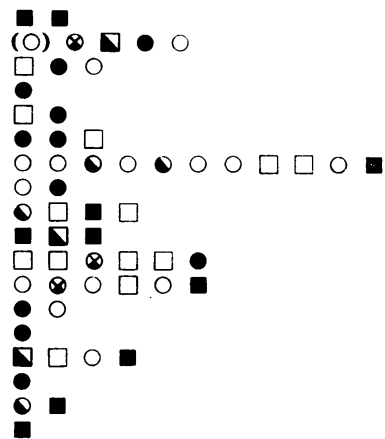 \\
\hline
\end{tabular}

sions and of these 5 had a known blood group incompatibility (Table 1). While prematurity, acidosis, and dehydration evidently contributed to the hyperbilirubinaemia, they were not constantly severe and it appears that in CCD some additional factor may be involved.

Diagnosis. In the newborn the diagnosis is established when there is hydramnios and watery diarrhoea in which the faecal concentration of $\mathrm{Cl}^{-}$exceeds $90 \mathrm{mmol} / \mathrm{l}$. A stool sample is easily obtained from the rectum with a soft catheter.

\section{Later manifestations; with no treatment}

A few CCD infants will survive the first months without adequate replacement therapy. In most patients reported from other countries and in 4 of our own (Table 1) the diagnosis was not made until they were between 6 months and $2 \cdot 5$ years old.

Diarrhoea. Of our late diagnosed children RJ was admitted to hospital aged 2 days for hyperbilirubinaemia and pneumonia and discharged 6 weeks later. 'Soft stools' were noticed during this period. At home neither she nor patient AT were ever known to pass a formed stool. Diarrhoea in MV was first noticed in a nursery in which he was placed when 3 month old. The mother of LI noticed soft stools at the age of 6 months and later watery diarrhoea. In all these patients the characteristically high faecal concentration of $\mathrm{Cl}^{-}$was subsequently shown.

Urine. All children in whom the diagnosis was made after the age of 6 months had $\mathrm{Cl}^{-}$-free urine, which has been considered characteristic of CCD. Fig. 6 shows, however, that the presence or absence of 


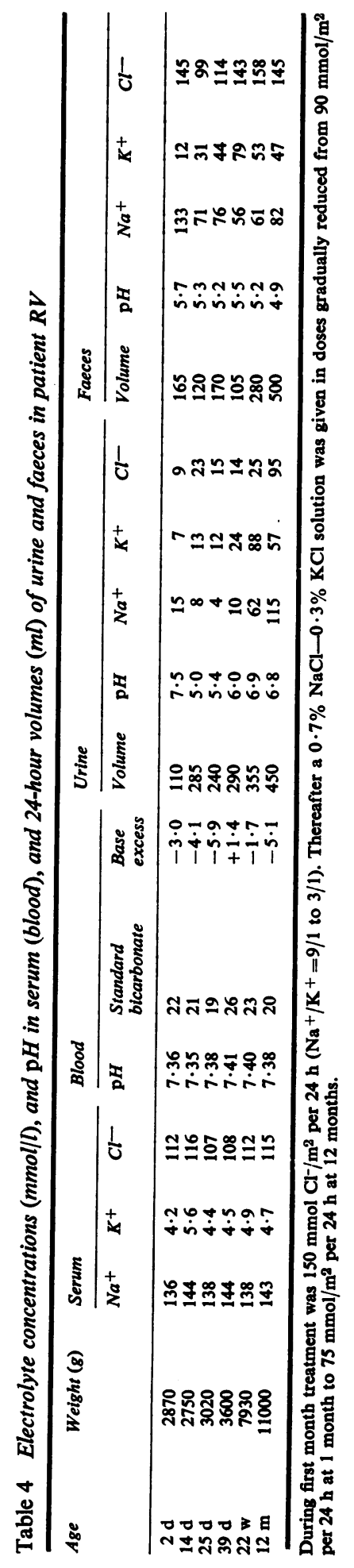




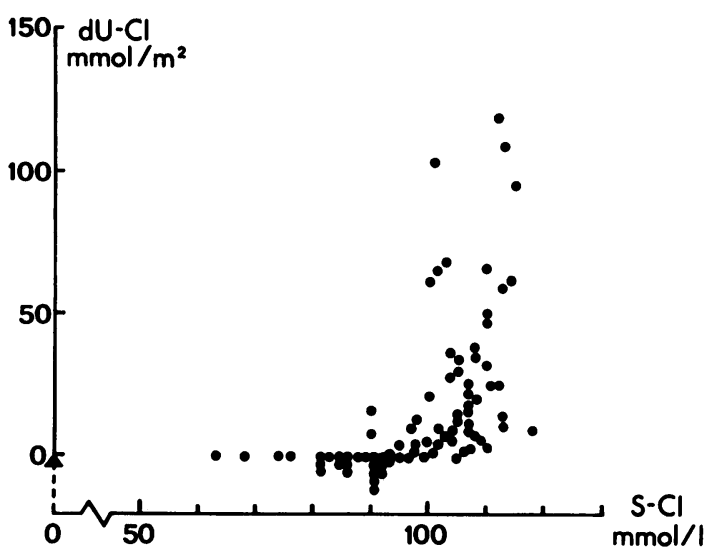

Fig. 6 Relationship of serum $\mathrm{Cl}^{-}$concentration to daily urinary $(\mathrm{dU}) \mathrm{Cl}^{-}$excretion in $C C D$ patients.

chloriduria depended on the serum $\mathrm{Cl}^{-}$concentration. Only serum $\mathrm{Cl}^{-}$levels below about $95 \mathrm{mmol} / 1$ were associated with absence of chloriduria, which is therefore characteristic of inadequately treated CCD only.

Electrolyte and acid-base status. The clinical picture of these untreated patients conformed with that described earlier for CCD: hypokalaemia and hypochloraemia with metabolic alkalosis. Their serum $\mathrm{Na}^{+}$concentration was normal (Table 2). This situation differs from that in the newborn in whom a hypochloraemia is associated with hyponatraemia (Fig. 5). In older patients the organism probably reacts to the hyponatraemia and dehydration (of which the serum $\mathrm{Cl}^{-}$concentration is an indicator) with hyperaldosteronism (Holmberg, 1977). $\mathrm{Na}^{+}$ absorption and $\mathrm{K}^{+}$excretion are stimulated both in the kidney and intestine (Fordtran and Ingelfinger, 1968; Sharp and Leaf, 1973) resulting in normonatraemia and hypokalaemia. Because of the high net intestinal and renal $\mathrm{H}^{+}$excretion, $\mathrm{HCO}_{3}^{-}$accumulates and a metabolic alkalosis results.

Growth and development. Before treatment, weight and longitudinal growth of CCD patients was retarded. The 4 patients who were diagnosed late (RKo, AS, LI, AT) showed at age 6 months a mean deviation of $-1.9 \mathrm{SD}$ (range -1.1 to $-3.0 \mathrm{SD}$ ) from the height expected for their age and parental height. Their weight was even more retarded. The children were in poor general condition, wasted, and inactive. MK, the oldest patient we treated, was in poor condition during the first 3 years of life because of inadequate replacement therapy and at the age of 1 year had marked osteoporosis (Fig. 7). His serum $\mathrm{Ca}^{++}$was 2.9 and inorganic $\mathrm{P} 1.6 \mathrm{mmol} / 1$; urinary

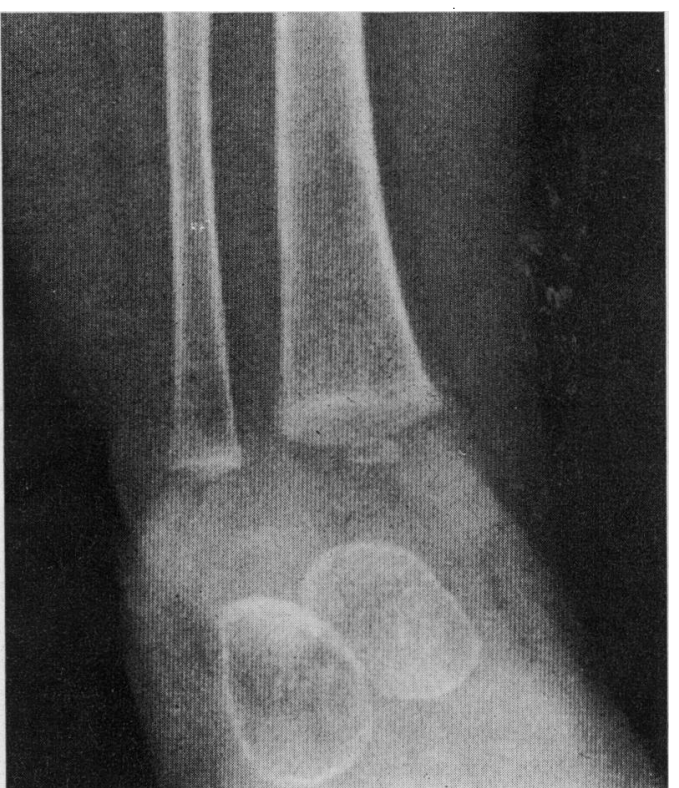

Fig. 7 Ankle x-ray of patient $M K$ at age 1 year showing marked osteoporosis.

concentration of $\mathrm{Ca}^{++}$was $1 \cdot 1$ and inorganic $\mathrm{P} 35 \cdot 1$ $\mathrm{mmol} / 1$; urine was $\mathrm{Cl}^{-}$-free. LI had a spontaneous fracture of the humerus at the age of 4 months and was unable to sit at 14 months. Untreated patients evidently have poor mineralization of bones owing perhaps to a loss of phosphate into the urine. AT developed surprisingly well, presumably due to her large spontaneous intake of salt and water. In our early patients delayed bone maturation (Greulich and Pyle, 1959) paralleled retarded growth.

Diagnosis. After the neonatal period hypokalaemia, hypochloraemia, and metabolic alkalosis are common but not inevitable. There is a history of prematurity and hydramnios. The final diagnostic criterion is the high faecal concentration of $\mathrm{Cl}^{-}$. However, in severely and chronically dehydrated and hypoelectrolytaemic infants this concentration was as low as $\mathbf{4 0} \mathbf{~ m m o l} / \mathrm{l}$. It (again) always exceeded $90 \mathrm{mmol} / \mathrm{l}$ once the dehydration and hypochloraemia had been corrected.

\section{Treatment}

Table 5 shows how we treated all our patients. To our earlier patients we gave only $\mathrm{KCl}$ at a dose sufficient to maintain normal serum electrolyte levels. Most of them, however, remained slightly alkalotic and their urine was $\mathrm{Cl}^{-}$-free (Pasternack et al., 1967). When examination of renal biopsy specimens 
Table 5 Chloride substitution requirements of the CCD patients during the previously used $\mathrm{KCl}$ substitution and the present $\mathrm{NaCl}+\mathrm{KCl}$ substitution

\begin{tabular}{llll}
\hline & \multicolumn{1}{l}{ Age } & & \\
\cline { 2 - 4 } Treatment & $0-1 \mathrm{yr}$ & $3-6 \mathrm{yr}$ & $8-11 \mathrm{yr}$ \\
\hline $\mathrm{KCl}$ & $100(47-195)$ & $99(60-204)$ & $68(45-95)$ \\
& $\mathrm{n}=7$ & $\mathrm{n}=10$ & $\mathrm{n}=3$ \\
$\mathrm{NaCl}+\mathrm{KCl}$ & $124(80-216)$ & $155(60-171)$ & $89(68-130)$ \\
as $\mathrm{KCl}$ & $48(20-108)$ & $47(12-85)$ & $34(11-43)$ \\
& $\mathrm{n}=10$ & $\mathrm{n}=7$ & $\mathrm{n}=8$
\end{tabular}

For criteria of adequate dose, see text. The mean (range) of dose is given, in $\mathrm{mmol} / \mathrm{m}^{2}$ per $24 \mathrm{~h}$.

showed hypertensive arteriolar changes, juxtaglomerular hyperplasia, nephrocalcinosis, and hyalinized glomeruli in the presence of high renin, angiotensin II, and aldosterone activities (Pasternack and Perheentupa, 1966; Pasternack et al., 1967), it was clear that our mode of replacement therapy was not satisfactory. Whereas high $\mathrm{K}^{+}$intake enabled $\mathrm{Na}^{+}$ to be spared, it evidently did so through a hormonal adjustment that caused arteriolar pathology (Holmberg et al., 1977). Therefore, since 1972 we have used a $\mathrm{NaCl}$ solution and added only enough $\mathrm{KCl}$ to meet the individual need for $\mathrm{K}^{+}$.

Newborns. Replacement therapy must be started immediately. Once the existing extracellular deficits are corrected, the child needs approximately 10 mmol $\mathrm{Cl}^{-} / \mathrm{kg}(1-2 \mathrm{mmol}$ as $\mathrm{KCl}$ and the rest as $\mathrm{NaCl}$ ) in iso-osmolal solution every 24 hours intravenously from the first day of life, in addition to normal requirements. These amounts are then adjusted for weight and serum electrolyte concentrations. If acidosis develops the dose is reduced. Peroral feeding can be started immediately in small amounts every 2-3 hours, the portions being gradually increased depending on weight and abdominal distension. Frequent insertion of a rectal tube helps to control distension. Peroral electrolyte replacement can usually be started on the third or fourth day, the dose being slowly increased and the intravenous dose correspondingly reduced. With our most recent patients we successfully moved to full oral feeding and electrolyte substitution by the age of 3 to 4 weeks. For oral replacement we used a $0.7 \%$ $\mathrm{NaCl}-0 \cdot 3 \% \mathrm{KCl}$ solution. To those patients in whom hyponatraemia and hyperkalaemia tended to develop on this solution a $0.9 \% \mathrm{NaCl}-0.2 \% \mathrm{KCl}$ solution was given for the first 4-5 months. The dose is adjusted to achieve normal serum electrolyte concentrations and $p \mathrm{H}$ and to maintain some chloriduria, conditions henceforth referred to as adequate condition. The infants were discharged when their weight exceeded $3 \mathrm{~kg}$, which in recent years occurred by the time they were 2-3 months old.

Older patients. Patients received the $0.7 \% \mathrm{NaCl}-$ $0.3 \% \mathrm{KCl}$ solution until about the age of 3 years. There after, for practical reasons, they were given a more concentrated solution together with free allowance of water. Because a slight hypokalaemia often tended to develop at this stage, the proportion of $\mathrm{K}^{+}$was increased. Hence the solution of older patients, taken in 3-4 daily doses at meals, contained $1.8 \% \mathrm{NaCl}$ and $1.9 \%$ of $\mathrm{KCl}$. The smallest dose was given which would maintain chloriduria. If hypokalaemia and alkalosis persisted on this dose, the concentration of $\mathrm{KCl}$ in the solution was increased to $2 \cdot 2 \%$ to achieve normal $p \mathrm{H}$ and $\mathrm{K}^{+}$concentration. The required daily dose of $\mathrm{Cl}^{-}$per $\mathrm{m}^{2}$ of body surface area varied for each patient but decreased slightly with age (Table 5). The parents made the solution, 1 litre at a time, from preweighted portions of the salts, and boiled water.

Acute exacerbations. Electrolyte balance remained labile and was disturbed even by slight infections. Gastrointestinal infections with diarrhoea and vomiting, though not unusually frequent, were especially disruptive. When substitution was interrupted because of vomiting, and fluid loss was increased owing to an acceleration of the diarrhoea, a life-threatening degree of dehydration developed with unusual speed. This state was associated with hypoelectrolytaemia, and an extremely rapid loss of $\mathrm{K}^{+}$. Volume had to be corrected vigorously to limit further loss of $\mathrm{K}^{+}$, and up to $10 \mathrm{mmol} \mathrm{K}^{+}$per $\mathrm{kg}$ were needed during the first 24 hours. In such an acute state sufficient water and electrolytes must be given (1) to replace volume and concentration deficits, (2) to provide the normal substitution dose of the patients, and (3) to provide the requirements of a normal child of the same size. All water and electrolytes must be given intravenously and nothing should be given orally until rehydration is achieved, and vomiting has stopped.

\section{Later course; with treatment}

Diarrhoea. Fig. 8 shows stool composition at different ages. Osmolality was lower than in the ultrafiltrate of normal stools (Wrong et al., 1965). $\mathrm{Cl}^{-}$ concentration was high, $p \mathrm{H}$ low, and $\mathrm{HCO}_{3}^{-}$ absent. The concentrations of the other ions were normal except for a low $\mathbf{M g}^{++}$concentration. Because volume was greater than normal, however, the daily excretion of this ion was in the normal range. For this same reason, excretion of $\mathrm{Na}^{+}$and $\mathrm{K}^{+}$were increased. Diarrhoea did not subside with 


\section{FAECES}

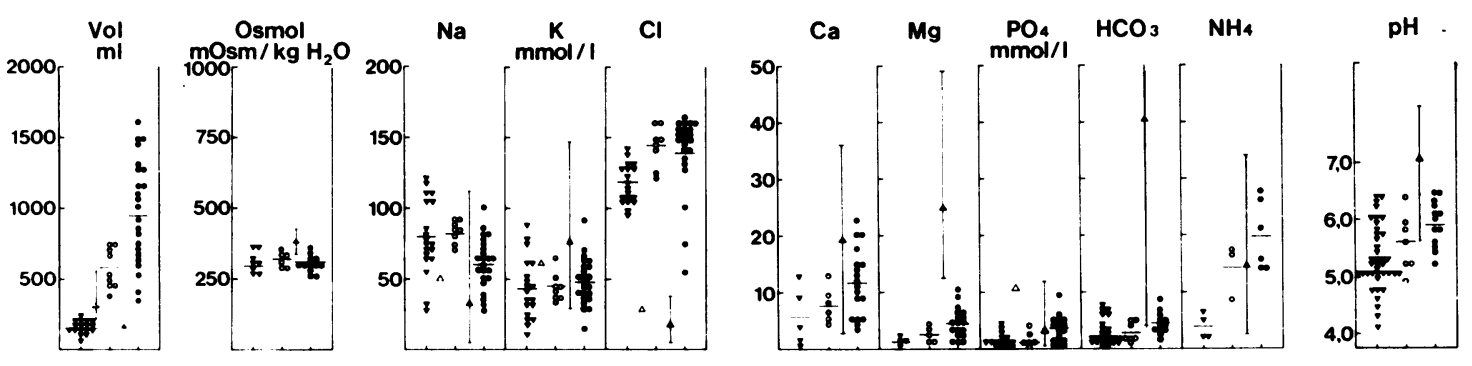

\section{U R I N E}
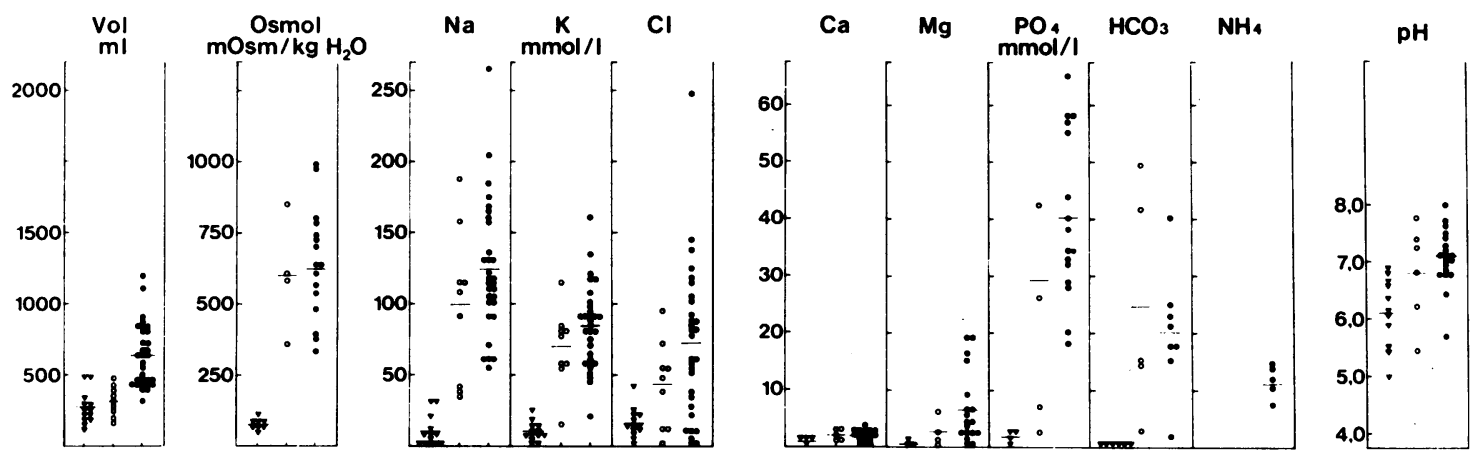

Fig. 8 Electrolyte composition of faeces and urine in CCD patients at different ages $(\nabla=<3 \mathrm{~m} ; 0=1-3 \mathrm{yr}$; $0=6-12 \mathrm{yr}$ ). All patients were in adequate condition when the collecions were made. $\triangle=$ normal mean (with range for volume) for diarrhoeal stools in infants (Holt et al., 1915) and $\bar{S}=$ mean and range for concentrations of faecal dialysates from older normal subjects (Wrong et al., 1965). Conversion: SI to traditional units-Ca: $1 \mathrm{mmol} / 1$ $\approx 4.0 \mathrm{mg} / 100 \mathrm{ml} . \mathrm{Mg}: 1 \mathrm{mmol} / \mathrm{l} \approx 2.4 \mathrm{mg} / 100 \mathrm{ml} . \mathrm{PO}_{4}: 1 \mathrm{mmol} / \mathrm{l} \approx 3.1 \mathrm{mg} / 100 \mathrm{ml}$.

increasing age. On the contrary, the absolute volume tended to increase slightly. With age $\mathrm{Na}^{+}$concentration fell whereas $\mathrm{K}^{+}$remained constant, and concentration of $\mathrm{Cl}^{-}$rose slightly.

Interestingly, the faeces became more alkaline with age. This was associated with an increase in the faecal content of non- $\mathrm{Na}^{+}-\mathrm{K}^{+}$cations, mainly $\mathrm{NH}_{4}^{+}$. Whether $\mathrm{NH}_{3}$ was produced by the mucosa or by bacteria is not known, but it presumably facilitated the absorption of $\mathrm{Na}^{+}$by binding $\mathrm{H}^{+}$, which was secreted in exchange for $\mathrm{Na}^{+}$. CCD children learned to control defecation later than normal. However, the 10 children over 7 years of age were dry during the day and defecated 3-5 times daily. 4 of them were always clean at night and 4 of them most nights. 2 soiled their bed regularly; one of them (MH) had an unusually profuse diarrhoea and the other (MK) severe psychological difficulties apparently unrelated to the disease. An increase in stool volume always accompanied respiratory infections.
Urine. Fig. 8 shows the composition of urine in patients in adequate condition. All had persistent chloriduria. $\mathrm{Na}^{+}$and $\mathrm{K}^{+}$concentrations and the $\mathrm{Na}^{+}-\mathrm{K}^{+}$ratio were within normal limits indicating normal aldosterone activity. $p H$ tended tó be abnormally alkaline, a tendency that became more pronounced with age. This alkalinity was evidently due to the loss of $\mathrm{H}^{+}$into the intestine (Holmberg et al., 1975), which left the balance of $\mathrm{HCO}_{3}^{-}$to be excreted by the kidney.

$\mathrm{Mg}^{++}$excretion was less than $0.06 \mathrm{mmol} / \mathrm{kg}$. Ghazali and Barratt (1974) reported that in English children $\mathrm{Mg}^{++}$excretion is normally $0.116 \pm 0.032$ (SD) $\mathrm{mmol} / \mathrm{kg}$. Hence $\mathrm{Mg}^{++}$excretion in our patients was depressed. Excretion of all other ions was in the normal range. Glucosuria and aminoaciduria were not observed. Renal handling of $\mathrm{Cl}^{-}, \mathrm{Na}^{+}$, and $\mathrm{K}^{+}$, and renal concentrating capacity appeared to be normal. Fig. 9 shows the relationship between the urinary $\mathrm{Na}^{+}-\mathrm{K}^{+}$ratio and the serum $\mathrm{Cl}^{-}$concen- 


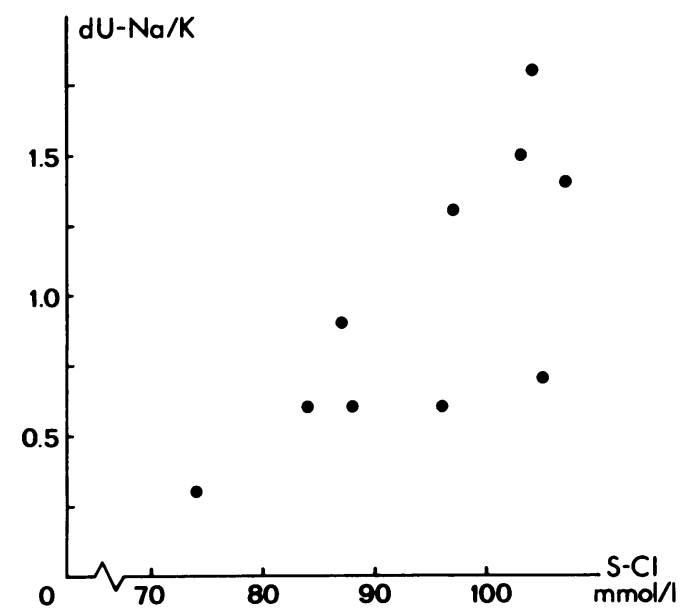

age of $14 \cdot 5$ years. Our 4 youngest patients did not show any essential deviation from the expected height at the age of 6 months in contrast to the untreated patients (see above). The mean deviation from expected height at the latest observation was $-0 \cdot 2 \mathrm{SD}$ (range $-2 \cdot 1$ to $+2 \cdot 0$ ) for all patients, and their weight was also normal.

Those children whose diarrhoea was profuse and whose electrolyte loss was therefore difficult to substitute for, had a distended abdomen. KR (Fig. 10a) was an extreme example. Most infants, however, did not have a prominent abdomen (Fig. 10b-d). Yet when examined radiographically the intestinal loops of the patients were distended with fluid and

Fig. 9 Relationship of $(d U)$ urinary $\mathrm{Na}^{+}-\mathrm{K}^{+}$ratio to serum $\mathrm{Cl}^{-}$concentration in patient $S A$.

tration, which reflects extracellular volume (Holmberg, 1977). The kidney evidently reacted normally to increased aldosterone activity. Acute situations with severe hypokalaemia and alkalosis were often seen associated with 'paradoxic aciduria'. Renal pathology, glomerular function, and the low $\mathbf{M g}^{++}$ excretion will be discussed elsewhere (Holmberg et al., 1977; Holmberg, 1977).

Laboratory investigations. Ileal and rectal biopsies were performed; tests for antibodies against gluten and cows' milk protein were made; and faecal fat and sugars, serum Fe and total iron binding capacity, urinary amino acids, 17-ketogenic and 17-ketosteroids, growth hormone and cortisol responses to insulin hypoglycaemia were determined in those patients whose growth remained retarded during treatment (MH, LI, PI, and AS). All findings were normal. Repeated estimations showed serum $\mathrm{Ca}^{++}$, inorganic phosphate, and alkaline phosphatase concentrations to be normal. Because high serum concentrations of uric acid have been reported in CCD (Gorden and Levitin, 1973; Pearson et al., 1973) this was measured but was normal $(n=19$, mean \pm SD $3 \cdot 4 \pm 1 \cdot 1$ $\mathrm{mg} / 100 \mathrm{ml}(0 \cdot 2 \pm 0.07 \mathrm{mmol} / \mathrm{l})$; normal range $2 \cdot 5-5 \cdot 5 \mathrm{mg} / 100 \mathrm{ml}(0 \cdot 15-0 \cdot 32 \mathrm{mmol} / \mathrm{l})$.

Growth and physical findings. In our early patients physical development was retarded in the first years of life but thereafter proceeded normally when treatment was adequate. The height of the oldest patient MK at age 3 years showed a deviation of $-4 \cdot 0 \mathrm{SD}$ from the height expected for age and parental height but had caught up to -0.6 by his present

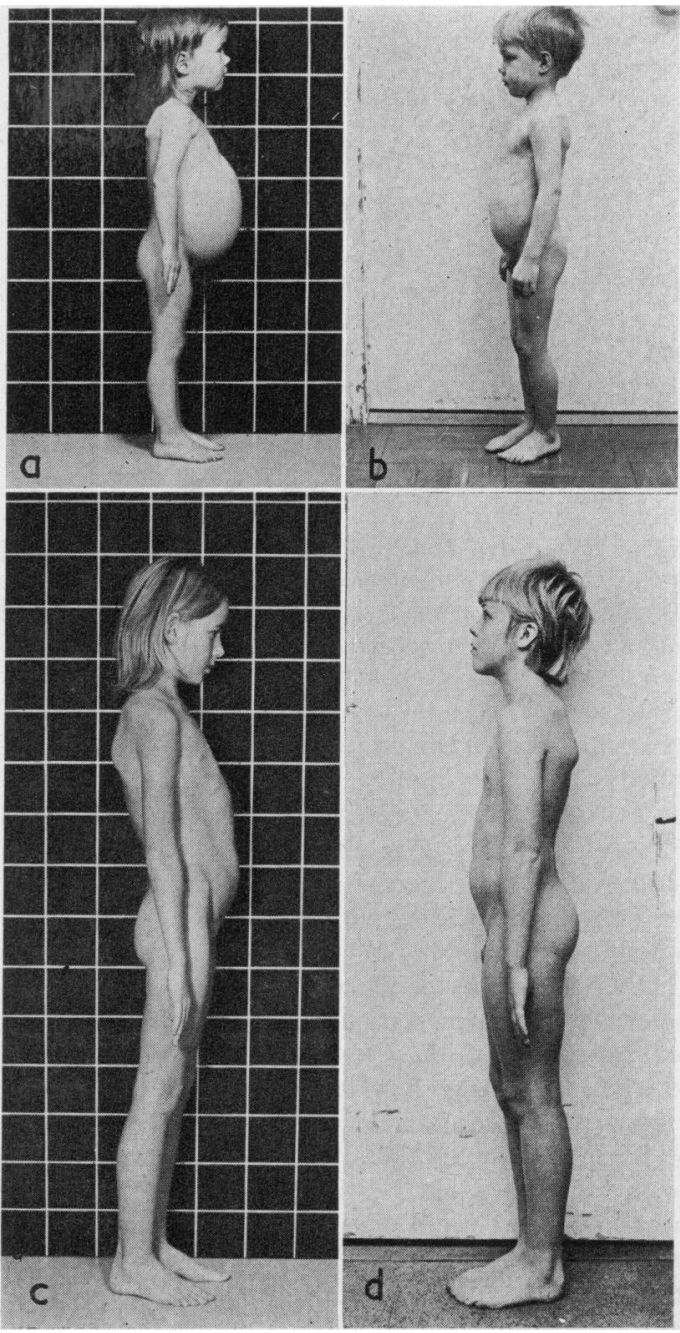

Fig. $10 C C D$ patients $K R, H P, R K o$, and $J H$ at ages $3,4,9$, and 10 years (see text). 
air, which led the radiologist to diagnose an ileus if he did not know the child had CCD. Otherwise, the appearance of the children was normal and all had normal blood pressure. Enamel hypoplasia of the teeth was common in the early patients but not in the later ones. All patients had a reduced incidence of dental caries (Myllärniemi and Holmberg, 1975).

Intellectual and motor development. Mental retardation has been associated with CCD (Darrow, 1945; Kelsey, 1954; Duyck, 1955; Owen, 1964; Tucker, et al., 1964; Harteman, 1966; Yssing and FriisHansen, 1966; Hager-Malecka et al., 1973). Of our 18 living patients, 10 have reached school age. 8 attend a regular school and perform normally; 2 are in a special class for slow learners, performing the best in their group. Patient AT, in whom the diagnosis was made at 24 months, performed for her age and had developed normally except for retarded growth.

Nine of the schoolchildren were evaluated psychometrically; 2 performed at a good mean level for their age, 4 at a low normal level, and 3 subnormally. Testing of all preschool children failed to show any retardation. Our early patients had slightly retarded motor development in infancy but no neurological abnormality could be detected later. The more recent patients all had normal motor development. We do not have exact psychometric data on the sibs of our patients and hence cannot make a comparison of performance within families.

Severe neonatal jaundice and prolonged poor condition owing to insufficient substitution seem to have resulted in slight mental retardation in some of our early patients. Adequate treatment from birth almost certainly assures normal intellectual and psychomotor development.

Accompanying diseases. In the first years of life most patients had frequent respiratory infections. HP had pleurisy and empyema at the age of 1 year; the left basal lobe was resected and he has since done well. RJ had pneumonia with atelectasis of the lingula that was corrected with conservative therapy. TR had numerous bouts of pneumonia. A bronchial biopsy and bronchoscopic examination at the age of 3 showed slight changes of chronic bronchitis. At the age of 4 she still occasionally had pneumonia.

Urinary tract infections were frequent in our early patients but are rare with our present mode of treatment (Holmberg et al., 1977). AS had occasional bloody stools; a rectal biopsy and sigmoidoscopic examination at the age of 12 showed a nonspecific colitis. Otherwise the children did well and after the first 2-3 years needed only yearly check-ups.

\section{Discussion}

That CCD is inherited as an autosomal recessive trait was shown by Norio et al. (1971) and has since been corroborated. Of 3 patients from outside Finland, one was the product of incest (Harteman, 1966), one of a marriage of first cousins (Yanagisawa et al., 1968), and one of a marriage of halfsibs (McReynolds et al., 1974). The families of the Finnish CCD patients have all come from the northern and eastern parts of the country, where the pool of other rare recessive genes is large (Norio et al., 1973). Among our 18 families, 3 have each had 2 children with CCD and a total of 7 other infants have died, in retrospect probable cases of CCD. In the 21 families reported from outside Finland, 5 also had a probable case of CCD (Kelsey, 1954; Evanson and Stanbury, 1965, 2 cases; Davidson et al., 1972; Pearson et al., 1973). Sex distribution does not differ; of the $\mathbf{4 2}$ known patients, 23 were male and 19 female.

Perfusion studies have shown that lack or impairment of active $\mathrm{Cl}^{-} / \mathrm{HCO}_{3}^{-}$transport in the ileum and colon that result in faecal $\mathrm{Cl}^{-}$loss and osmotic diarrhoea is probably the primary defect in CCD (Turnberg, 1971; Bieberdorf et al., 1972; Pearson et al., 1973; Holmberg et al., 1975). Though faecal concentrations of $\mathrm{Na}^{+}$and $\mathrm{K}^{+}$are normal, there is a loss of these ions because stool volume is large. Perfusion studies have also shown that the impairment of $\mathrm{Na}^{+}$absorption is secondary to the acidity of the intestinal contents. Initial losses therefore are mostly of $\mathrm{Cl}^{-}$and $\mathrm{Na}^{+}$; accordingly, the first serum electrolyte disturbances we recorded were hypochloraemia and hyponatraemia. That those disturbances were detected already 1 hour after birth with hydramnios invariably present and meconium lacking is strong evidence of intrauterine diarrhoea. Evidence of prenatal disturbances was also noted in 17 of the non-Finnish patients: hydramnios in 9, prematurity or a birthweight below $2500 \mathrm{~g}$ in 8 , and a lack of meconium in 2 .

In the first days of life severe dehydration develops that is usually iso-osmolal, but may already then be markedly hypo-osmolal. In inadequately treated infants dehydration will always become hypo-osmolal during the first week. Serum $\mathrm{K}^{+}$concentration may remain normal and a distinct alkalosis at this stage is rare. If no treatment is instituted serum $\mathrm{Na}^{+}$ content rises to normal concentrations and hypokalaemia, hypochloraemia, and metabolic alkalosis develop. The body compensates for the electrolyte disturbance through an increase in the absorption of $\mathrm{Na}^{+}$and water in the kidney and intestine at a cost of a loss of $\mathrm{K}^{+}$in these organs. The alkalosis probably develops partly through an associated increase in 
$\mathrm{H}^{+}$excretion and partly through an absence of $\mathrm{HCO}_{3}^{-}$secretion in the ileum and colon.

All our early patients, i.e. those not diagnosed at birth and in whom replacement therapy was inadequate, had renal involvement. They were slightly alkalotic, had hyperaldosteronism, and no chloriduria. Similar histories and clinical findings along with similar results in renal biopsy examinations have been reported for 4 non-Finnish patients; 2 were diagnosed at 6 months of age (Hager-Malecka et al., 1973; McReynolds et al., 1974), one at 2 years (Hartemann, 1966), and one at 6 years (Loeb et al., 1970). Examination of renal biopsy specimens taken from our more recent patients in whom adequate substitution was made from birth showed that renal histology was normal and renal function unimpaired. Hence renal involvement is not a primary feature of CCD but develops as a result of inadequate replacement therapy (Holmberg et al., 1977). Our findings speak against any specific renal tubular defect and the intestinal defect affects only $\mathrm{Cl}^{-} /$ $\mathrm{HCO}_{3}^{-}$transport.

Several attempts at reducing the diarrhoea have been made. Evanson and Stanbury (1965) reported success with $\mathrm{Cl}^{-}$restriction and $\mathrm{KHCO}_{3}$ therapy, but we as well as others (Davidson et al., 1972; Pearson et al., 1973; McReynolds et al., 1974) have failed. Our patients went into severe dehydration and hypoelectrolytaemia. Pearson et al. (1973) tried codeine phosphate, diphenoxylate hydrochloride, synthetic polysaccharide, and an anion exchange resin but failed to reduce the faecal volume. The only situation in which we have observed reduction of diarrhoea has been chronic hypovolaemia and hypoelectrolytaemia, which clearly is an undesirable state for the patient (Holmberg, 1977).

Retarded mental development has been attributed to CCD in 8 patients (see above). 2 were diagnosed at the age of 1 month, the others between the ages of 6 months and 2 years and hence all had experienced a long period of severe fluid disturbance in early life. Their early treatment cannot be evaluated from the reports. Of our patients, the early poorly treated ones has slight retardation of mental, statural and skeletal development. Our later patients in whom adequate replacement therapy was begun at birth manifest no such retardation. We thus feel justified in concluding that with adequate substitution CCD children develop normally.

The diagnosis of CCD is simple. It can be tentatively made from the typical history of hydramnios, prematurity, and watery diarrhoea, and then confirmed from the high faecal concentration of $\mathrm{Cl}^{-}$. Serum electrolyte and $p \mathrm{H}$ changes are not reliable diagnostic criteria. Without treatment most children die in infancy but some will achieve a spontaneous electrolyte balance and survive with retarded psychomotor development. The extreme example is the patient of Pearson et al. (1973) in whom the diagnosis was made when he was 21 years old. Because the severity of the disease varies with each patient, the composition and amount of the electrolyte solution needed also varies. Optimum therapy should fully substitute for the faecal loss of $\mathrm{Cl}^{-}$, $\mathrm{Na}^{+}, \mathrm{K}^{+}$, and water. The best criteria of adequate substitution are normal serum electrolyte concentrations, normal blood $p \mathrm{H}$, and the presence of slight chloriduria. Thus, treatment in CCD aims at substituting for the diarrhoea, and in fact maintaining it. According to present knowledge, all attempts to stop or alleviate it are futile and dangerous. The patients will learn to live with their diarrhoea and to make an adequate social adjustment.

This study was supported by grants from the National Research Council for Medical Sciences, Finland.

\section{References}

Bayard, F., Beitins, I. Z., Kowarski, A., and Migeon, C. J. (1970). Measurement of aldosterone secretion rate by radioimmunoassay. Journal of Clinical Endocrinology, 31, 507-510.

Bieberdorf, F. A., Gorden, P., and Fordtran, J. S. (1972). Pathogenesis of congenital alkalosis with diarrhea. Journal of Clinical Investigation, 51, 1958-1968.

Bremer, D., and Heinisch, H.-M. (1973). Bilanzuntersuchungen bei einem Säugling mit congenitaler Chloriddiarrhoe. Monatsschrift für Kinderheilkunde, 121, 403-405.

Chaptal, J., Jean, R., Dossa, D., Meylan, F., Morel, G., and Rieu, D. (1967). Diarrhée chlorée congénitale. Étude clinique et biologique d'une observation de l'enfant. Annales de Pédiatrie, 16, 326-334.

Darrow, D. C. (1945). Congenital alkalosis with diarrhea. Journal of Pediatrics, 26, 519-532.

Davidson. A. G. F., Insley, J., Capps, F. P. A., and Anderson, C. M. (1972). Familial chloride diarrhoea (congenital alkalosis with diarrhoea). Australian Paediatric Journal, 8, 187-190.

Duyck, E. M. R. A. (1955). L'alcalose congénitale avec diarrhée. Aspects du métabolisme mineral. Thesis, Stenfert Kroese, Leyden.

Evanson, J. M., and Stanbury, S. W. (1965). Congenital chloridorrhoea or so-called congenital alkalosis with diarrhoea. Gut, 6, 29-38.

Fordtran, J. S., and Ingelfinger, F. J. (1968). Absorption of water, electrolytes, and sugars from the human gut. Handbook of Physiology, Section 6: Alimentary Canal, Vol. 3, Chap. 74, p. 1457. Ed. by C. F. Code. American Physiological Society, Washington. D.C.

Gamble, J. L., Fahey, K. R., Appleton, J., and MacLachlan, E. (1945). Congenital alkalosis with diarrhea. Journal of Pediatrics, 26, 509-518.

Ghazali, S., and Barratt, T. M. (1974). Urinary excretion of calcium and magnesium in children. Archives of Disease in Childhood, 49, 97-101.

Gorden, P., and Levitin, H. (1973). Congenital alkalosis with diarrhea. A sequel to Darrow's original description. Annals of Internal Medicine, 78, 876-882. 
Greulich, W. W., and Pyle, S. J. (1959). Radiographic Atlas of Skeletal Development of the Hand and Wrist, 2nd ed. Stanford University Press, Stanford, California.

Hager-Malecka, B., Sychlowy, A., Kuźniarz, K., and Smigla, K. (1973). Congenital nephropathy and chronic diarrhoea with hypokalemic alkalosis. Zeitschrift für Kinderheilkunde, 114, 31-38.

Harries, J. T. (1969). Congenital chloridorrhoea. Archives of Disease in Childhood, 44, 647-648.

Harteman, E. (1966). Diarrhée chlorée congénitale avec alcalose métabolique. Thesis, Lyon.

Holmberg, C. (1977). On the pathophysiology of congenital chloride diarrhoea. To be published.

Holmberg, C., Perheentupa, J., and Launiala, K. (1975). Colonic electrolyte transport in health and in congenital chloride diarrhea. Journal of Clinical Investigation, 56, 302-310.

Holmberg, C., Perheentupa, J. and Pasternack, A., (1977). The renal lesion in congenital chloride diarrhea. Journal of Pediatrics (in press).

Holt, L. E., Courtney, A. M., and Fales, H. L. (1915). The chemical composition of diarrheal as compared with normal stools in infants. American Journal of Diseases of Children, 9, 213-224.

Kelsey, W. M. (1954). Congenital alkalosis with diarrhea. American Journal of Diseases of Children, 88, 344-347.

Luaniala, K., Perheentupa, J., Pasternack, A., and Hallman, N. (1968). Familial chloride diarrhea-chloride malabsorption. Modern Problems in Pediatrics, Vol. 11, p. 137. Ed. by D. H. Shmerling, H. Berger, and A. Prader. Karger, Basel.

Lauras, B., Francois, B., Duc, H., Genoud, J., David, M., and Jeune, M. (1973). Contribution a l'étude de la diarrhée chlorée congénitale. Archives Françaises de Pédiatrie, 30, 491-503.

Lee, T. R., and Harries, J. T. (1973). Congenital chloridorrhoea. Proceedings of the Royal Society of Medicine, 66, 348-349.

Loeb, H., Petit, P., Vainsel, M., Buyle, M. L., and Piepsz, A. (1970). Congenital chloride diarrhea. (Abst.). Pediatric Research, 4, 214.

McReynolds, E. W., Roy, S., III, and Etteldorf, J. N. (1974). Congenital chloride diarrhea. American Journal of Diseases of Children, 127, 566-570.

Michalsen, H. (1972). Congenital chloride diarrhoea. Acta Paediatrica Scandinavica, 61, 615-618.

Myllärniemi, S., and Holmberg, C. (1975). Caries resistance in children with congenital chloride diarrhoea. Archives of Oral Biology, 20, 239-240.

Norio, R., Perheentupa, J., Launiala, K., and Hallman, N. (1971). Congenital chloride diarrhea, an autosomal recessive disease. Genetic study of 14 Finnish and 12 other families. Clinical Genetics, 2, 182-192.

Norio, R., Nevanlinna, H. R., and Perheentupa, J. (1973). Hereditary diseases in Finland; rare flora in rare soil. Annals of Clinical Research, 5, 109-141.

Owen, G. M. (1964). Metabolic alkalosis with diarrhrea and chloride-free urine. Journal of Pediatrics, 65, 849-857.
Pasternack, A., and Perheentupa, J. (1966). Hypertensive angiopathy in familial chloride diarrhea. Lancet, 2 , 1047-1049.

Pasternack, A., Perheentupa, J., Launiala, K., and Hallman, N. (1967). Kidney biopsy findings in familial chloride diarrhoea. Acta Endocrinologica, 55, 1-9.

Pearson, A. J. G., Sladen, G. E., Edmonds, C. J., Tavill, A. S., Wills, M. R., and McIntyre, N. (1973). The pathophysiology of congenital chloridorrhoea. Quarterly Journal of Medicine, 42, 453-466.

Perheentupa, J., Eklund, J., and Hallman, N. (1965). Chronic diarrhea and alkalosis. Pediatrics, 35, 506.

Sharp, G. W. G., and Leaf, A. (1973). Effects of aldosterone and its mechanism of action on sodium transport. Handbook of Physiology, Section 8: Renal Physiology, Chap. 25, p. 815. American Physiological Society, Washington, D.C.

Tucker, V. L., Wilmore, D., Kaiser, C. J., and Lauer, R. M. (1964). Chronic diarrhea and alkalosis. Pediatrics, 34, 601-608.

Turnberg, L. A. (1971). Abnormalities in intestinal electrolyte transport in congenital chloridorrhoea. Gut, 12, 544 551.

Wrong, O., Metcalfe-Gibson, A., Morrison, R. B., Ng, S. T., and Howard, A. V. (1965). In vivo dialysis of faeces as a method of stool analysis. I. Technique and results in normal subjects. Clinical Science, 28, 357-375.

Yanagisawa, M., Obe, Y., and Yabuta, K. (1968). A case of congenital alkalosis with diarrhea. Paediatria Universitatis Tokyo, 16, 44-47.

Yssing, M., and Friis-Hansen, B. (1966). Congenital alkalosis with diarrhea. Acta Paediatrica Scandinavica, 55, 341-344.

Correspondence to Dr. C. Holmberg, Children's Hospital, University of Helsinki, Helsinki, Finland, SF 00290.

\section{Addendum}

Since this paper was written we have seen one more patient with CCD, born in 1976 after 36 weeks' gestation as the second child of his family. The first child had been a stillbirth after a pregnancy complicated with hydramnios. There was again hydramnios. The infant's birthweight was $2540 \mathrm{~g}$, and Apgar score 6. He was not doing well and did not gain weight: 'loose stools' were noted. At the age of 3 weeks serum $\mathrm{Na}^{+}$was $116, \mathrm{~K}^{+} 3 \cdot 0$, and $\mathrm{Cl}^{-} 80$ $\mathrm{mmol} / \mathrm{l}$. CCD was suspected and the child transferred to our hospital. The stool composition was $\mathrm{Na}^{+}$ $76, \mathrm{~K}^{+} 50$, and $\mathrm{Cl}^{-} 112 \mathrm{mmol} / \mathrm{l}$ (after correction of deficits). The child has been doing well on the $0.7 \%$ $\mathrm{NaCl}-0.3 \% \mathrm{KCl}$ solution, and was discharged at the age of 7 weeks with a weight of $3300 \mathrm{~g}$. 